\title{
Postcolonial Reading of a Colonial Text
}

\author{
Majed hamed Aladaylah ${ }^{1}$ \\ ${ }^{1}$ Department of English, Mutah University, Al-Karak, Jordan \\ Correspondence: Majed hamed Aladaylah, Department of English, Mutah University, Al-Karak, Jordan. E-mail: \\ aladylah@yahoo.com
}

Received: May 21, 2012 Accepted: June 1, 2012 Online Published: July 30, 2012

doi:10.5539/elt.v5n9p122 URL: http://dx.doi.org/10.5539/elt.v5n9p122

\begin{abstract}
The discussion and analysis focuses on the ways colonialist discourse, in this case Maugham's short story Footbrint in the jungle, positioned the colonized natives into European colonialist socio-cultural hierarchy. This study examines Maugham's depictions of non-white communities - Malay, Chinese and Indian. Hence, we look at how this colonialist writer reinforced and spread the idea of physical and social differences between the Europeans and the non-European races, rendering the latter an inferior position to the former. In this section we see that the distinction made was not only rooted in physically grounds but culturally and socially as well, which go hand in hand with Edward Said's notion of Orientalism.

The analysis shows that Maugham's narrative represents the Eastern social and cultural practices in an unpalatable manner. For example, the geography and landscape of the colonized territory is sketched as evil, savage, dark, et cetera. We see the forest in Maugham's The Footprinst in the Jungle as a place where everything becomes dangerous: people lose their sanity; loves takes on the face of violence and hatred.
\end{abstract}

Keywords: postcolonial, orientlaism, discourse, narrative, colonized, marginalized

This research paper based on Said's notion of Orientalism, the imperial idea that fundamental cultural differences between the European and non European world was profoundly important to the civilizing mission in a number of ways. For example, the characterization of non-European societies as backward and primitive legitimized conquest of these societies and justified the measures colonial powers used to control and transform these peoples. Antony Anghie tries to show the role of international law in legitimizing colonialism: the civilizing mission's hidden agenda (Anghie, 2005: 5-6).

There are a number of reasons behind British colonialism and expansion. Denis Judd (1996: 3-5) explains that there is no question that the existence of the Empire brought profit and wealth to a section of the British population; the desire for profitable trade, plunder and enrichment was the primary force that led the establishment of the imperial structure. The Empire served many other purposes, such as it provided a means of outdoor relief for a substantial number of the upper and middle classes personals. The Empire rule over indigenous peoples also provided the colonizer with easy psychological defense mechanism: principally upon inferior black and brown people which seemed to boost the confidence, persona, financial and sexual aggrandizement of the white individual and nation in manifold opportunities. In addition to that, it introduced strange exotic foods, foreign flora and fauna, vocabulary, indigenous cultures, and a whole host of different ways of living into the British experience. For instance, the British expansion throughout Southern Africa created a cheap, readily available, supply of African labor through conquest (Paulin 1999: 1). The opening up of colonized ports to British-based trade and European commercial entrepreneurism established British colonization from country to country and from continent to continent, but resulted in the dislocation of the local economy of the place and the manipulation of indigenous markets and industries. As far as colonialism is concerned, Kathrin Onyiaorah (2000) also displays that, by twenty-first century, the number of British colonies had reduced drastically. The twentieth century brought with it the colonial downfall, and the decolonization of millions of people, who were once subject to the British crown. Colonies from Canada to Gibraltar, India, Malaya and Africa belonged to the British Empire of the $19^{\text {th }}$ Century. As discussed, British colonialism expanded its territories looking for material and trade, which was the prime reason for the capture of new territories. Trade also included the trade of human beings - slaves. The slave trade by the British started sometime in $16^{\text {th }}$ Century and continued with a growing rate till it was abolished in 1833. This trade of the human flesh resulted in subordination and subjugation of the colonized societies. 
To conclude, I wish to point here that one country is not necessarily colonized only by one colonial power, there are countries which have been colonized by a number of different European colonizers. This resulted in the competition between those European countries. In other words, the most powerful won the colony: the colony became a trophy of the European colonizing race.

Street states that the white man will always occupy the highest rank, followed by the native, a rank located a bit higher than the animal's is used by European man to scale man's civilization (Street 1975: 78-80). Presiding over this hierarchy, in colonialist discourse, is the European male character. The myth that the European man is always a survivor and the fittest, which is projected through colonialist writings, is a colonialist ideology. Next, on this hierarchy of representation, is the European female character. Only then comes the non-European male, and, lastly, lowest on the ladder is the non-European female character. The characters that are given a voice are mostly always the European characters, especially the male characters. In Maugham's Footprints in the Jungle, Gaze talks about Mrs. Cartwright:

I've known Mrs. Cartwright for over twenty years," he said slowly. "She wasn't a bad-looking woman in those days ... she was young it didn't seem to matter so much. It was rather attractive. She was married to a man called Bronson Reggie Bronson (Maugham 1993: 7).

In the above excerpt, we see that the European male character, Gaze, is given a voice to express his opinion of Mrs. Cartwright. Through him, the readers get a projection of Mrs. Cartwright, who is depicted as not a bad looking woman. This act of speaking about another character reflects the social hierarchy discussed in the preceding paragraph. Gaze definitely seems to have a higher placing in this story as compared to Mrs. Cartwright, who is a European female character, as he is given the authority to describe her: the readers see her through his eyes. This is one example which makes evident that the European male characters are in the centre of narration in colonialist discourse.

Western discourse during colonialism was full of stereotypes of the East, which perpetuated the notion of difference between the former and the latter. According to Edward Said, when the Europeans came to the East, they thought that "the main thing for the European visitors was a European representation of the Orient" (1995: 1). Perhaps, to the Europeans, the people of the East were incapable of representing themselves, and as such took this burden upon themselves. As a result, there emerged representations of the East that were derogatory and full of stereotypes. Since Western world view at that time was rooted in imperial ideology, the East, instead of being represented, was misrepresented, at times advertently and at other times unconsciously. Facts were manipulated and the East was deformed in the eyes of the world. Edward Said elaborates:

... the Orient was almost a European invention, and had been since antiquity a place of romance, exotic being, haunting memories and landscapes, remarkable experiences (Said 1995: 2).

Therefore, we see how the term 'Orient' is actually the invention of the West to divide the world for political and economical reasons. This is perhaps what Said means by the Orient is the creation "of the living tableau of queerness (1995: 104)." The binary separation was a means of projecting the West as superior and the East as backward. In sum, the Occident deformed the Orient to form its 'Self'.

Likewise, Maugham's The Footprints in the Jungle represents the native woman character as ageing before time.

She was a woman somewhere in the fifties, with white hair very untidily arranged, and a constant gesture with her was an impatient movement of the hand to push back a long wisp of the hair that kept falling over her forehead (Maugham 1986: 3).

The excerpt above tries to show how women in the East tend to look old very quickly. Gaze, the character who is a policeman in the story, remarks, "It ages one before one's time (Maugham 1993: 9)." These kinds of remarks become stereotypical overgeneralizations. Because one woman, for some reason or another looks older than her age, the East is represented as a place where people age quickly.

Thus, we see how isolated cases, perpetuated by colonialist ideology, are generalized to negatively represent the colonized world. These colonialist narratives, such as Maugham's, we see block the colonized peoples into physical bondage and show them in a light that is inferior to the colonial 'Self'.

Even the colonized land is depicted as primitive and dangerous in colonialist discourse, and constantly compared to the Western earth, which is represent as beautiful, serene, et cetera. Here, I provide textual evidences from Maugham's Footprints in the Jungle and Neil MacAdam. In one story, a murder takes place, and in the other, a person is lost and found dead. Both these tragedies take place in the Malayan jungle. Therefore, the Malayan jungle, as depicted by Maugham, comes to signify evil, death and savage. With this, the attention of the reader is narrowed, from a general situation, to the representation of the Orient as a place that harms. 
The excerpt below from Maugham's Footprints in the Jungle relates the Malayan landscape with images of death and decay.

But in our silence the din of the jungle was deafening; those damned cicadas and the bull-frogs were making enough row to wake the dead. Even under ordinary circumstances the noise of the jungle at night is uncanny; because it has an odd effect on you, that ceaseless and invisible uproar that beats upon your nerves. It surrounds you and hems you in. Believe me it was terrifying. That poor fellow lay dead and all round him the restless life of the jungle pursued its indifferent and ferocious course (1993: 23-24).

The above representation of the Malayan landscape is indeed terrifying. Colonialist discourse is filled with such negative representations of the colonized world to ensure that physical differences between the East and the West are maintained. These ugly stereotypical images were means to achieve the imperial agenda.

Maugham's description of the physical appearances of the natives and their way of life in his discourse, which takes a Eurocentric stand, paints a primitive and uncivilized picture of the colonized world. This shows that colonialist writers, like Maugham, placed European culture at the centre and all other cultures at the fringe of their narration.

The colonialist representation of bondage through stereotypes goes back far in time. Ania Loomba states that racial stereotyping can be traced right back to the Greek and Roman periods. In medieval and early modern Europe, Christianity and Islam were opposing forces. It was then that negative images of the East were spread. Religious, racial, cultural and ethnic differences were highlighted. During the rise of colonialism, these ideas were further intensified, expanded and reworked. Stereotypes, constructed by European nations, to construct the 'Other' were "laziness, aggression, violence, greed, sexual promiscuity, bestiality, primitivism, innocence and irrationality" (Loomba 1998: 107). Continuous repetitions of these impressions about the colonized stereotyped the other.

Maugham's Footprints in the Jungle is an example of colonialist discourse that represents the colonized peoples with negative images: the Malays and Chinese are described as extravagant, murderers and gamblers. These stereotypes create a boundary between the 'Self' (West) and the 'Other'. Mr and Mrs. Cartwright, in the story, are never questioned about Bronson's murder because they are Europeans and therefore are supposedly always innocent. When the murder takes place, the first suspect is the Chinese. "I think a pair of Chinks might think out a trick like that..." (Maugham 1993: 22). Next on the suspect lists were "the coolies of his estate" (27). This again puts blame on the non-Europeans. Aggression and violence is constantly associated with the Chinese and the Indians. No fingers are pointed towards the European. The character, Gaze, generalizes and stereotypes the Malays and Chinese when investigating Mr. Bronson's murder:

I felt I knew the native temperament enough to be sure that the possession of it was a constant temptation. The Malays are an extravagant race and a race of gamblers, and the Chinese are gamblers, too; sooner or later someone would start flinging his money about, and then I should want to know where it came from. (1993: 27).

The excerpt above produces a negative generalization of the people of the East, stereotyping them as thieves and murderers. This kind of generalizations, made on minimal observation, is extended to represent all the colonized peoples. Coming back to the story, when the officer finds that the Malay is not brave enough to murder, the Chinese is accused and tortured, while the actual murderer escapes punishment. This verifies the earlier discussion in Chapter Three (section 3.3.3) that the colonizer viewed the colonized people as socially inferior and placed them on very low ebb on the scale of civilization.

On the other hand, colonialist discourse portrayed the Europeans as civilized. For instance, the European woman, in Footprints in the Jungle, is depicted as socially charming and graceful, in a manner that totally contrasts the native's image, as seen below:

I thought her a very agreeable person. I liked her frankness. I liked her quick wit. I liked her plain face. I never met a woman who obviously cared so little how she looked... but none of this mattered. Everything she wore was perfectly in character (1993: 4).

Although this woman is seen to have a "plain face", yet she is liked by the narrator: for she "was perfectly in character". This is one of the many descriptions in colonialist narratives which highlight the Europeans as sociable, pleasant and smart, and in control of their life and behaviour. These kinds of mighty images are then contrasted with denigrating descriptions of the natives, so that the Europeans look even higher on the scale of civilization.

These kinds of stereotypes, which are actually based on assumptions, confirm John Mcleod's argument that "Orientalism makes assumptions about race (Mcleod 2000: 44)." Edward Said elaborates, "The relationship 
between Occident and Orient is relationship of power, domination, of varying degrees of a complex hegemony (Said, 1995: 6)."

Maugham's short stories on Malaya, as we have seen so far, emphasize and reinforce these stereotypes of the colonizer-colonized relationship. Homi Bhabha states that the West fixes stereotypes in its representation of the colonized people, as seen in the statement below:

An important feature of colonial discourse is its dependence on the concept of 'fixity' in the ideological construction of otherness. Fixity as the sign of cultural/historical/racial difference in the discourse of colonialism, is a paradoxical mode of representation: it connotes rigidity and unchanging order as well as disorder, degeneracy and daemonic repetition. Likewise the stereotype, which is its major discursive strategy, is a form of knowledge and identification that vacillates what is always 'in place', already known, and something that must be anxiously repeated (Bhabha 1994: 66).

Fixity and repetition is evident in Maugham's narration. His short stories of Malaya repeatedly portray the native characters in a negative light. As a result, the colonized peoples got a derogatory image.

For instance, Maugham's Footprints in the Jungle, through repetition, reinforces a depiction of the unruly native and abnormal native land.

The government offices are still in the old Raad Huis that the Dutch built when they owned the land, and on the hill stand the grey ruins of the forty by aid of which the Portuguese maintained their hold over the unruly natives You know how many fellows when they come out east seem to stop growing (Maugham 1993: 1-12).

As seen in the above excerpt, colonialist narratives demonstrate European superiority and show them in control of the colonized other, who is depicted as unruly. The phrase "stop growing" implies that there is something abnormal about the land as if the place interferes with the growth of a person.

John McLeod also identifies Orientalism as "a study of how the Western colonial powers of Britain and France represent North Africa and Middle Eastern lands in the late nineteenth and early twentieth centuries (McLeod 2000: 39). However, the analyses here examine Maugham's narratives by using Said's theory of binary opposition of the East and West. The study explores the texts and the author and the complex collective formation against which selected texts of the colonialist writer are set. By way of the intertextual method of analysis and I will lay bare and challenge the representation of the colonized as exotic and masculine-looking and uncivilized Other by setting Maugham's short fiction against colonialist postcards, a travelogue written by an anonymous Western tourist and other forms of popular culture. A postcolonial reading of these texts will allow for the involvement of the colonized in the formation of identity.

Thus so far we have seen that colonialist discourse is abundant with negative portrayals of the colonized peoples. Colonial ideology is achieved through comparison - binary opposition: the colonial form versus the native formlessness, colonial order versus native chaos, et cetera. These comparisons are the basis of colonial hegemony.

Therefore, we see that the relationship between the Occident and the Orient is based on binary oppositions. Europeans were categorized as superior, civilized, advanced, sophisticated, brave, rational, and intelligent, while the natives were portrayed to be blood-thirsty, stupid, slave of customs, irrational, lazy et cetera. This 'created' an urgent need to put everything in order; imperial intervention was considered an absolute necessity. In accordance, it was the most natural thing for the European race to intervene, dominate, control and rule the Orient. More than that, since the natives, depicted as devoid of natural intelligence, were incapable of utilizing fully their natural environment for their benefit, Europeans had to carry out the job for them. These binary opposites were broadcasted to legitimize their presence in the East.

The West employed its power of discourse over the East, and it did not permit the Orientals to represent themselves and their culture. This illustrates Said's notion of power: in Orientalisim as a Western style for dominating, restructuring, and having authority over the Orient (Said 1995: 3).

During the nineteenth century, the Industrial Revolution gave certain countries in Western Europe vast economic power. Countries such as, France, Britain, and Germany emerged as industrialized powers, with high population and high production. During the time when Social Darwinism was popular, it was only natural that these nations compete with each other for survival (BookRages 2006). The most important agenda for Europeans to colonize, during the $19^{\text {th }}$ and $20^{\text {th }}$ Centuries, was to support their own countries economically and to compete with the other European powers. One of the main ways a colony could help its colonizer is by providing it with another economic market. As a result of Industrialization, production was too high as compared to demand in Europe. That indicates, unless there is another market to sell their national products employment could decline drastically 
within the nation and eventually cause riots. Therefore, Jules Ferry, French Prime Minister, wrote an appeal to the Government, demanding for colonization in his request notes:

We must say openly that the higher races have a right over the lower races. The very structure of the colonial enterprise shows the exploitation of the natives. The Europeans sought to exploit these colonies in order to achieve even higher levels of profit and economic gain (Mega Essay 2008).

The quotation above clearly reveals the desire to exploit the other and is rooted deeply in the common belief that Europeans were the dominant race. Also because products need consumers, colonization became the resolution, which perpetuated imperial authoritative beliefs. Thus, we see how the traits of conquering and dominating other people and their territories are stemmed from Western colonial ideology.

Thus, we have seen how colonialist narratives, in this case Maugham's short story, indulged in the construction of binary oppositions and stereotypes, based on racial differences, which deformed, denigrated, marginalized and misrepresented the East. This physical, social, and psychological aspect created misleading and incorrect notions of the colonized subject. In other words, the negative portrayal of the colonized peoples in discourse was actually an imperial ideology to justify colonial rule.

\section{References}

Anghie, A. (2005). Imperialism, Sovereignty and the Masking of International Law. Cambridge University Press. Retrieved February 1, 2010, from http://www.cambridge.org/uk/catalogue/catalogue.asp?isbn=0521828929

Bhabha, K. H. (1994). The Location of Culture. Routledge.

Dennis, T. G. (2001). The Crusades from the Perspective of Byzantium and the Muslim World. Dumbarton Oaks Research Library and Collection. Retrieved 20 June 2010, from http://www.doaks.org/crusades/cr03.pdf

Loomba, A. (1998). Colonialism/Postcolonialism. London: Rutledge.

Loomba, A. (2001). Colonialism/Postcolonialism. London: Rutledge.

Maugham, S. W. (1993). Far Eastern Tales. Mandarin Paperback. Great Britain.

McLeod, J. (2000). Beginning Postcolonialism. Manchester: Manchester University Press.

MegaEssays. (2008). Colonial Enterprise. Retrieved 16 December 2010, from http://www.megaessays.com/viewpaper/16230.html

Onyiaorah, K. (2000). British Colonialism in William Somerset Maugham's Short Story. Nutzerwertug: 68 von 100 Bewertung Abgeben. Retrieved 11 January 2007, from http://www.hausarbeiten.de/faecher/vorschau/103957.html

Paulin, C. M. (1999). White men's dreams, Black men's blood: African labor and British expansionism in southern Africa, 1877-1895. The University of Connecticut. Retrieved 20 November 2010, from http://proquest.umi.com/pqdlink?Ver=1\&Exp=08-11-2013\&FMT=7\&DID=730312121\&RQT=309\&attemp $\mathrm{t}=1 \& \mathrm{cfc}=1$

Said, W. E. (1994). Culture and Imperialism. Vintage. London.

Said, W. E. (1995). Orientalism. Pantheon Books a division of Random House Inc.

Street, B. V. (1975). The savage in literature. London: Rutledge \& Kegan Paul.

Streissguth, T. (2001). Slavery. Greenhaven Press. 